\title{
Genetic diversity of European populations of the invasive soft-shell clam Mya arenaria (Bivalvia)
}

\author{
Rafal Lasota**${ }^{\ddagger}$, Herman Hummel ${ }^{\dagger}$ and Maciej Wolowicz* \\ *Laboratory of Estuarine Ecology, Institute of Oceanography, Gdansk University, Al. Marszalka Pilsudskiego 46, \\ 81-378 Gdynia, Poland. ${ }^{\dagger}$ Centre for Estuarine and Marine Ecology, Netherlands Institute of Ecology, Korringaweg 7, \\ 4401 NT Yerseke, The Netherlands. ${ }^{\ddagger}$ Corresponding author, e-mail: rlasota@sat.ocean.univ.gda.pl
}

\begin{abstract}
The genetic diversity of the soft-shell clam Mya arenaria from seven locations in Europe (two stations in the southern Baltic Sea (the Gulf of Gdansk) and two in the North Sea (Veerse Meer and Oosterschelde), and three additional stations in the Denmark Straits and Bay of Biscay) was determined using starch gel electrophoresis of allozymes. The results showed a low level of genetic variability and a lack of genetic differentation among the populations studied. Basic polymorphism characteristics calculated for populations from the North Sea estuaries and the Gulf of Gdansk were: He 0.094-0.145, Ho 0.092-0.130, percentage of polymorphic loci 33 (0.95 criterion), mean number of alleles per locus 2.0-2.7. The mean value of $\mathrm{F}_{\mathrm{ST}}$ was 0.0133 and not significant. It is concluded that in spite of a low level of genetic polymorphism the soft-shell clam is a successful colonizer. The genetic homogeneity among the populations reflects rapid population extension, alleles neutrality and a high gene flow.
\end{abstract}

\section{INTRODUCTION}

The soft-shell clam Mya arenaria originated on Pacific coasts in the Miocene. In the late Miocene it extended its range to the west coasts of the Atlantic. In Europe, the soft-shell clam appeared in the late Pliocene. It has remained in America since the Pliocene whereas it died out in Europe at the beginning of the Pleistocene. According to Peterson et al. (1992), who dated shells from Kattegat, the soft-shell clam reinvaded Europe in the 13th Century and might have been transported from North America by the Vikings. It reinvaded the Pacific east coast probably through oyster transplants from the Atlantic to San Francisco Bay prior to 1874. The last step in the invasion history of the soft-shell clam was the unintentional introduction from the Baltic Sea to the Black Sea around 1960. Today Mya arenaria is widely distributed over boreal waters and is often a dominant species in local shallow water benthic communities. It has also an important commercial value in some regions of North America. The soft-shell clam is a relatively large $(60-100 \mathrm{~mm}$, maximally $150 \mathrm{~mm})$ and long-lived bivalve. It inhabits mainly intertidal and shallow subtidal waters but has been found even at a depth of $192 \mathrm{~m}$. Depending on the geographical region soft-shell clams spawn once or twice per year. The fecundity value for one spawning period can vary between 120 thousand to three million eggs. The larval phase usually lasts for 2-3 weeks. Mya arenaria is an eurytopic species. It lives in the salinity range 4-35 psu and can easily survive salinity fluctuations of $15 \mathrm{psu}$. The southern limit of distribution is determined probably by a temperature of $28^{\circ} \mathrm{C}$. A temperature of $10-$ $12^{\circ} \mathrm{C}$ for spawning and $12-15^{\circ} \mathrm{C}$ for succesful larval development determines the northern limit of distribution (see Strasser, 1999 for references).

Even though the soft-shell clam is such a common species, very little is known about its population genetics. Recent studies on the genetics of the soft-shell clam concerned only populations from the Atlantic coasts of North America and revealed a low level of allozyme variation in this species (Levinton, 1973; Morgan et al., 1978), which is in contrast to the hypothesis that animals living in an unstable, heterogeneous environment and able to colonize new habitats should possess high genetic variability (Hedrick et al., 1976; Ehrlich, 1986). The present paper is believed to be the first on the genetic diversity of European populations of Mya arenaria. This is especially surprising since Mya arenaria was probably the first species introduced into Europe by man. Colonization of a new area may be connected with processes causing a drastic decrease in population polymorphism, as predicted by theory (Chakraborty \& Nei, 1977) and observed in many species (e.g. Gallardo et al., 1995). Another theory predicts little influence of founding events on populations (Nei et al., 1975). Similarly, two different models concerning population structuring after founder events exist, predicting strong genetic structuring or reducing of genetic differentation between populations (Alvarez-Buylla \& Garay, 1994).

The aim of this study was to determine the level of genetic variation of some European populations using allozymes and characterize population structure at a macrogeographical scale with respect to historical and contemporary processes.

\section{MATERIALS AND METHODS}

Samples, consisting mainly of animals with a length of 10-30 mm, were collected in autumn 2001 from seven locations (Table 1, Figure 1). Animals were held alive in aquaria at $10^{\circ} \mathrm{C}$ or frozen at $-70^{\circ} \mathrm{C}$ until processed. Due to the very low number of individuals in the French and Swedish populations, the genetic structure has been discussed mainly on the basis of the results obtained for the Dutch and Polish populations. 
Table 1. Sampling stations, depth and numbers of animals for genetic analysis $(\mathcal{N})$.

\begin{tabular}{llrl}
\hline Station & Country & Depth & $($ N) \\
\hline 1. Mechelinki & Poland, the Gulf of Gdansk & 6 & 111 \\
2. Hel-45 & Poland, the Gulf of Gdansk & 45 & 50 \\
3. Lomma & Sweden, Sund & 1 & 12 \\
4. Lerhamn & Sweden, Kattegat & 1 & 6 \\
5. Oosterschelde & Netherlands, North Sea estuary & intertidal & 66 \\
6. Veerse Meer & Netherlands, North Sea estuary & 1 & 51 \\
7. Gironde & France, Bay of Biscay estuary & 6 \\
\hline
\end{tabular}
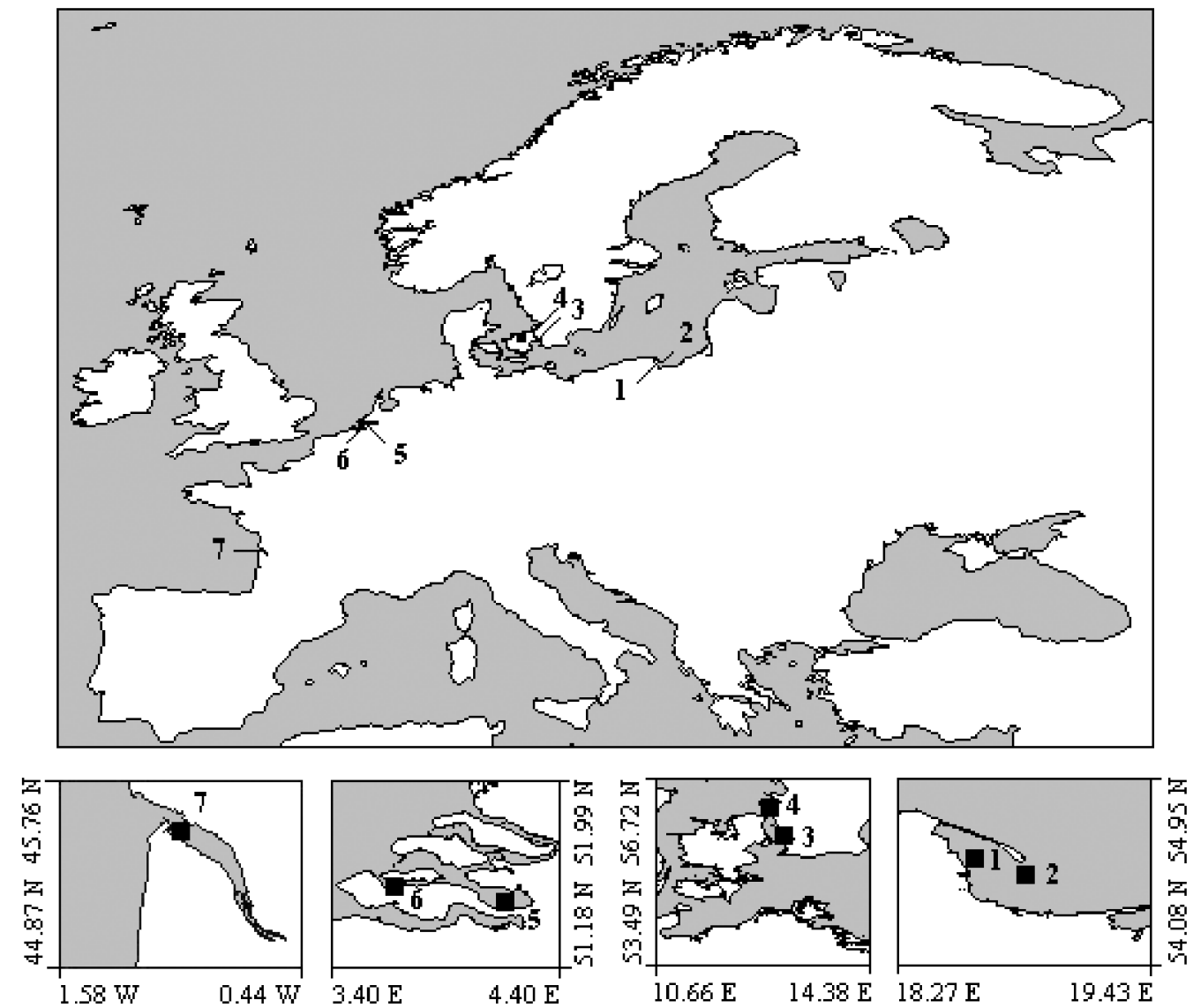

Figure 1. Location of the sampling stations. 1, Mechelinki; 2, Hel-45; 3, Lomma; 4, Lerhamn; 5, Oosterschelde; 6, Veerse Meer; 7, Gironde.

Genetic traits in the soft-shell clam were determined using standard starch gel electrophoresis of six enzyme systems (enzyme number and abbreviations in parentheses): glucosephosphate isomerase (Gpi E.C 5.3.1.9), isocitrate dehydrogenase (Idh E.C 1.1.1.42), leucine aminopeptidase (Lap E.C 3.4.1.1.1), malate dehydrogenase ( $M d h$ E.C 1.1.1.37), phosphogluconate dehydrogenase (Pgd E.C 1.1.1.44) and phosphoglucomutase (Pgm E.C 5.4.22). Electrophoresis and enzyme visualization were performed according to Menken (1982) and Hummel et al. (1995).

Single individual genotype data were analysed using BIOSYS-2 (original version: Swofford \& Selander, 1981; modified by Black, 1997) and LINKDIS (original version: Black \& Krafsur, 1985; rewritten to work with BIOSYS data set by Black, 1997). Observed heterozygosity (Ho), expected heterozygosity (He) (Nei's, 1978 unbiased esti- mate) and the mean number of alleles per locus as indices of genetic variability were determined for all studied populations. Selander's (1970) D statistic for the excess or deficiency of heterozygotes, $\chi^{2}$-test after pooling genotypes for testing the departure of genotype frequencies from Hardy-Weinberg expectations, Nei's (1977) F $_{\text {ST }}$ and analysis of linkage disequilibrium were determined only for populations from the Gulf of Gdansk and the North Sea. The other populations were excluded because of small sample size. Nei's $\mathrm{F}_{\mathrm{ST}}$ measures the amount of differentiation among subpopulations and was tested for significance with the usual $\chi^{2}$-test of heterogeneity of allele frequencies (Workman \& Niswander, 1970). Computation of $\mathrm{D}$ is not appropiate for almost-monomorphic loci (i.e. the dominant allele has a frequency $>0.8$ ) because of the predominant influence of rare alleles. To indicate when 
Table 2. Allele frequencies in the studied populations.

\begin{tabular}{|c|c|c|c|c|c|c|c|c|c|}
\hline $\begin{array}{l}\text { Population/ } \\
\text { enzyme }\end{array}$ & $\begin{array}{l}\text { Veerse } \\
\text { Meere }\end{array}$ & $\begin{array}{l}\text { Ooster- } \\
\text { schelde }\end{array}$ & $\begin{array}{l}\text { Meche- } \\
\text { linki }\end{array}$ & Hel-45 & $\mathrm{F}_{\mathrm{ST}}$ & $\begin{array}{l}\text { Average } \\
\mathrm{F}_{\mathrm{ST}}\end{array}$ & Gironde & Lerhamn & Lomma \\
\hline \multicolumn{10}{|l|}{$P G D$} \\
\hline $\mathrm{N}$ & 49 & 66 & 111 & 48 & & \multirow[t]{10}{*}{0.0136} & 3 & 6 & 12 \\
\hline $\mathrm{A}$ & 0.071 & 0.061 & 0.018 & 0.042 & 0.0117 & & 0.167 & 0.000 & 0.000 \\
\hline B & 0.082 & 0.061 & 0.077 & 0.104 & 0.0027 & & 0.167 & 0.083 & 0.000 \\
\hline $\mathrm{C}$ & 0.245 & 0.159 & 0.135 & 0.167 & 0.0109 & & 0.333 & 0.250 & 0.125 \\
\hline $\mathrm{D}$ & 0.582 & 0.720 & 0.761 & 0.688 & $0.0198 *$ & & 0.333 & 0.667 & 0.875 \\
\hline $\mathrm{E}$ & 0.010 & 0.000 & 0.005 & 0.000 & 0.0037 & & 0.000 & 0.000 & 0.000 \\
\hline $\mathrm{F}$ & 0.010 & 0.000 & 0.005 & 0.000 & 0.0037 & & 0.000 & 0.000 & 0.000 \\
\hline $\mathrm{He}$ & 0.596 & 0.453 & 0.398 & 0.492 & & & 0.867 & 0.530 & 0.228 \\
\hline Ho & 0.429 & 0.500 & 0.405 & 0.521 & & & 0.667 & 0.500 & 0.250 \\
\hline $\mathrm{D}$ & $-0.273 * *$ & 0.113 & 0.024 & 0.070 & & & & & \\
\hline \multicolumn{10}{|l|}{$P G M-1$} \\
\hline $\mathrm{N}$ & 51 & 50 & 110 & 50 & & \multirow[t]{8}{*}{0.0160} & 6 & 6 & 12 \\
\hline $\mathrm{A}$ & 0.020 & 0.040 & 0.014 & 0.040 & 0.0060 & & 0.000 & 0.000 & 0.042 \\
\hline B & 0.725 & 0.730 & 0.827 & 0.850 & $0.0169 *$ & & 1.000 & 0.833 & 0.917 \\
\hline C & 0.029 & 0.020 & 0.027 & 0.020 & 0.0006 & & 0.000 & 0.000 & 0.000 \\
\hline $\mathrm{D}$ & 0.225 & 0.210 & 0.132 & 0.090 & $0.0195 *$ & & 0.000 & 0.167 & 0.042 \\
\hline $\mathrm{He}$ & 0.426 & 0.425 & 0.299 & 0.270 & & & & 0.303 & 0.163 \\
\hline Ho & 0.451 & 0.400 & 0.300 & 0.260 & & & & 0.333 & 0.167 \\
\hline $\mathrm{D}$ & 0.070 & -0.050 & 0.009 & -0.028 & & & & & \\
\hline \multicolumn{10}{|l|}{$P G M-2$} \\
\hline $\mathrm{N}$ & 51 & 66 & 111 & 50 & & & 6 & 6 & 12 \\
\hline $\mathrm{A}$ & 0.020 & 0.015 & 0.009 & 0.000 & & & 0.000 & 0.000 & 0.000 \\
\hline $\mathrm{B}$ & 0.961 & 0.977 & 0.986 & 1.000 & & & 0.500 & 1.000 & 1.000 \\
\hline $\mathrm{C}$ & 0.010 & 0.008 & 0.005 & 0.000 & & & 0.500 & 0.000 & 0.000 \\
\hline \multirow{2}{*}{\multicolumn{10}{|c|}{$L A P-1$}} \\
\hline & & & & & & & & & \\
\hline $\mathrm{N}$ & 51 & 61 & 111 & 50 & & \multirow[t]{7}{*}{0.0096} & 5 & 6 & 12 \\
\hline A & 0.020 & 0.041 & 0.005 & 0.010 & 0.0125 & & 0.000 & 0.083 & 0.000 \\
\hline B & 0.902 & 0.861 & 0.941 & 0.940 & 0.0141 & & 1.000 & 0.833 & 0.875 \\
\hline $\mathrm{D}$ & 0.059 & 0.082 & 0.050 & 0.050 & 0.0031 & & 0.000 & 0.083 & 0.125 \\
\hline $\mathrm{E}$ & 0.020 & 0.016 & 0.005 & 0.000 & 0.0062 & & 0.000 & 0.000 & 0.000 \\
\hline $\mathrm{He}$ & 0.184 & 0.253 & 0.112 & 0.115 & & & & 0.318 & 0.228 \\
\hline Но & 0.196 & 0.164 & 0.090 & 0.120 & & & & 0.333 & 0.083 \\
\hline \multicolumn{10}{|l|}{$L A P-2$} \\
\hline $\mathrm{N}$ & 51 & 66 & 111 & 50 & & & 6 & 6 & 12 \\
\hline B & 0.990 & 0.992 & 1.000 & 1.000 & & & 1.000 & 1.000 & 1.000 \\
\hline C & 0.010 & 0.008 & 0.000 & 0.000 & & & 0.000 & 0.000 & 0.000 \\
\hline \multicolumn{10}{|l|}{$G P I$} \\
\hline $\mathrm{N}$ & 51 & 66 & 111 & 50 & & & 6 & 6 & 12 \\
\hline $\mathrm{A}$ & 0.000 & 0.015 & 0.005 & 0.010 & & & 0.000 & 0.000 & 0.000 \\
\hline B & 1.000 & 0.985 & 0.995 & 0.990 & & & 0.917 & 1.000 & 1.000 \\
\hline $\mathrm{C}$ & 0.000 & 0.000 & 0.000 & 0.000 & & & 0.083 & 0.000 & 0.000 \\
\hline \multicolumn{10}{|l|}{$I D H-1$} \\
\hline $\mathrm{N}$ & 51 & 66 & 111 & 50 & & & 6 & 6 & 12 \\
\hline B & 1.000 & 1.000 & 1.000 & 1.000 & & & 1.000 & 1.000 & 1.000 \\
\hline \multicolumn{10}{|l|}{$I D H-2$} \\
\hline $\mathrm{N}$ & 51 & 66 & 111 & 50 & & & 6 & 6 & 12 \\
\hline B & 1.000 & 1.000 & 1.000 & 1.000 & & & 1.000 & 1.000 & 1.000 \\
\hline \multicolumn{10}{|l|}{$M D H$} \\
\hline $\mathrm{N}$ & 51 & 66 & 111 & 50 & & & 6 & 6 & 12 \\
\hline B & 1.000 & 1.000 & 1.000 & 1.000 & & & 1.000 & 1.000 & 1.000 \\
\hline Average & & & & & & 0.0133 & & & \\
\hline $\mathrm{He}$ & 0.145 & 0.136 & 0.094 & 0.100 & & & 0.175 & 0.128 & 0.069 \\
\hline Ho & $(0.073)$ & $(0.063)$ & $(0.050)$ & $(0.058)$ & & & $(0.105)$ & $(0.067)$ & $(0.035)$ \\
\hline $\mathrm{D}$ & 0.130 & 0.128 & 0.092 & 0.102 & & & 0.204 & 0.130 & 0.056 \\
\hline \multirow{3}{*}{$\mathrm{N}$ alleles } & $(0.062)$ & $(0.064)$ & $(0.051)$ & $(0.060)$ & & & $(0.124)$ & $(0.067)$ & $(0.031)$ \\
\hline & -0.018 & -0.040 & -0.028 & 0.025 & & & & & \\
\hline & $\begin{array}{l}2.7 \\
(0.6)\end{array}$ & $\begin{array}{l}2.4 \\
(0.4)\end{array}$ & $\begin{array}{l}2.6 \\
(0.6)\end{array}$ & $\begin{array}{l}2.0 \\
(0.4)\end{array}$ & & & $\begin{array}{l}1.6 \\
(0.3)\end{array}$ & $\begin{array}{l}1.6 \\
(0.3)\end{array}$ & $\begin{array}{l}1.4 \\
(0.2)\end{array}$ \\
\hline
\end{tabular}

$\mathrm{N}$, number of specimens; He, expected heterozygosity; Ho, observed heterozygosity, standard deviation for mean He and Ho in parentheses; $\mathrm{D}$, heterozygote deficiency; $\mathrm{F}_{\mathrm{ST}}$, genetic differentiation; $*, P<0.05 ; * *, P<0.01$; average $\mathrm{D}$ calculated from all loci and not tested for significance. 
Table 3. $\chi^{2}$-test with pooling genotypes into three classes for testing the departure of genotype frequencies from Hardy-Weinberg expectation.

\begin{tabular}{|c|c|c|c|c|c|c|}
\hline Population & Locus & Class & Observed frequency & Expected frequency & $\chi^{2}$ & $P$ \\
\hline \multirow[t]{3}{*}{ Mechelinki } & $L a p-1$ & 1 & 100 & 98.381 & & \\
\hline & & 2 & 9 & 12.239 & & \\
\hline & & 3 & 2 & 0.381 & 7.773 & 0.005 \\
\hline \multirow[t]{3}{*}{ Veerse Meer } & $P g d$ & 1 & 21 & 16.577 & & \\
\hline & & 2 & 15 & 23.847 & & \\
\hline & & 3 & 13 & 8.577 & 6.744 & 0.009 \\
\hline \multirow[t]{3}{*}{ Oosterschelde } & $L a p-1$ & 1 & 48 & 45.184 & & \\
\hline & & 2 & 9 & 14.631 & & \\
\hline & & 3 & 4 & 1.184 & 9.036 & 0.003 \\
\hline
\end{tabular}

1, homozygotes for the most common allele; 2 , common/rare heterozygotes; 3 , rare homozygotes and other heterozygotes; $\mathrm{df}=1$.

significant linkage disequilibrium exists between loci polymorphic according to the 0.95 criterion a $\chi^{2}$-test following Weir's (1979) formula was used. Analysis of linkage disequilibrium was performed in each subpopulation and in the total population (all subpopulations combined). When significant disequilibrium was detected between loci a composite linkage disequilibrium coefficient $\Delta_{i j}$ (Cockerham \& Weir, 1977) and a correlation coefficient $\mathrm{R}_{i j}$ (Weir, 1979) were determined for each pair of alleles. The hypothesis that $\mathrm{R}_{i j}=0$ was tested by $\chi_{(1 \mathrm{df})}^{2}=\mathrm{NR}_{i j}^{2}$ (Weir, 1979). The effective number of migrants was estimated according to Wright (1965): $\mathrm{F}_{\mathrm{ST}}=1 /\left(1+4 \mathrm{~N}_{\mathrm{em}}\right)$. Nei's (1978) unbiased genetic identity was used to determine genetic identity between populations.

\section{RESULTS}

Identified loci, mean allele frequencies, mean heterozygosity and mean number of alleles per locus in the studied populations are given in Table 2. The results showed a high level of gene monomorphism. According to the 0.95 criterion, three of the nine identified loci were polymorphic. Loci Pgm-1, Lap-1 and Pgd were polymorphic in six populations. For the Dutch and Polish populations the mean number of alleles was 2.0-2.7 and was similar for all populations. In the populations from the Gironde and North Sea heterozygosity was slightly higher than in the Gulf of Gdansk. Significant departure of genotype frequencies from the Hardy-Weinberg expectation was found at locus Pgd in the population from Veerse Meer and locus Lap-1 in the populations from Mechelinki and Oosterschelde (Table 3). Significant heterozygote deficiency was observed at locus Pgd in the population from Veerse Meer (Table 2). $\mathrm{F}_{\mathrm{ST}}$ was significant for alleles $P g d$-D, Pgm-1-B and Pgm-1-D. The values of average $\mathrm{F}_{\mathrm{ST}}$ for Pgd, Pgm-1 and Lap-1 loci were 0.0096, 0.0051 and 0.0040, respectively, and were not significant (Table 2). The mean value of $\mathrm{F}_{\mathrm{ST}}$ was 0.0133 , and not significant. The genetic identity between the Dutch and Polish populations was 0.997-1.00. Statistically significant disequilibrium was found only in the population from Veerse Meer between loci Pgm-1 and Lap-1 $(P<0.05)$ and occurred between alleles Pgm-1 C and Lap-1 A $\left(\Delta_{i j}=0.00882, \mathrm{R}_{i j}=0.38638\right.$, $P<0.01), P g m-1 \mathrm{C}$ and Lap-1 B $\left(\Delta_{i j}=-0.01412, \mathrm{R}_{i j}=\right.$ $-0.30225, P<0.05), P g m-1 \mathrm{C}$ and Lap-1 E $\left(\Delta_{i j}=0.00882\right.$, $\left.\mathrm{R}_{i j}=0.38638, P<0.01\right)$. All these disequilibria involved rare alleles thus, according to Black \& Krafsur (1985), were probably artefacts. The effective number of migrants per generation was estimated to be 18 .

\section{DISGUSSION}

The basic polymorphism characteristics obtained in the present study (mean heterozygosity, per cent of polymorphic loci and mean number of alleles per locus) were similar to that reported for two populations of the softshell clam from the Atlantic coast of North AmericaMaine and Maryland (Morgan et al., 1978) when considering the same enzyme systems which were studied by us. The results showed a low level of genetic variation in the soft-shell clam as compared with other marine bivalves. For Macoma balthica, Cerastoderma edule and Mytilus sp. analysed using the same set of isoenzymes and the same methodology, mean heterozygosity ranged from 0.21 to 0.47 and the mean number of alleles from 3.0 to 5.7 (see Hummel et al., 1997, 2001, for references). However, in the bivalve Cerastoderma glaucum and the polychaete Arenicola marina mean heterozygosity was similar to that of Mya arenaria and ranged from 0.09 to 0.17 (see Hummel et al., 1997, for references). Further comparison with literature data also confirms the low genetic variation in the soft-shell clam. In Anomalocardia brasiliana, the percentage of polymorphic loci ranged from 50 to 60 , Ho from 0.19 to 0.26 (da Silva \& Solé-Cava, 1994), and in Mytilus desolationis Ho ranged from 0.2 to 0.7 (Blot \& Thiriot-Quiévreux, 1989). A very high level of genetic variation has been found in molluscs living in unstable, shallow water environment. For the bivalve Mulinia lateralis all 19 studied loci were polymorphic and Ho reaches the value of 0.408 (Wenne, 1992). An even higher level of genetic variation was found in the case of molluscs from the Red Sea which have colonized the Mediteranean Sea after the opening of the Suez Canal: the gastropods Cerithium scabridum and Cerithium caeruelum (Ho 0.61-0.66, all 20 scored loci polymorphic, mean number of alleles per locus 3.9-4.9) (Ritte \& Pashtan, 1982) and the bivalve Brachidontes variabilis (Ho 0.62-0.63, mean number of alleles per locus 5.5) (Safriel \& Ritte, 1986).

Mya arenaria has a very high tolerance of a wide range of environmental conditions and is a successful colonizer (Strasser, 1999). Thus, the low level of gene polymorphism in this species is in contrast to the hypothesis that animals 
living in an unstable, heterogeneous environment and able to colonize new habitats should possess high genetic variability (Hedrick et al., 1976; Ehrlich, 1986), and confirms recent studies suggesting little association between total genetic variability and a species' success as a colonizer (e.g. Lavee \& Ritte, 1994). Moreover, the results showed no genetic differentiation between populations from the stations with different environmental conditions. Although $\mathrm{F}_{\mathrm{ST}}$ for a single allele was significant in three cases, the values were very low. For bivalves with a high gene flow, average $\mathrm{F}_{\mathrm{ST}}$ amounts to 0.01 to 0.03 between populations at geographic distances of hundreds of kilometres, and 0.04 to 0.06 at distances of thousands of kilometres (see Hummel et al., 1997 for references). For the soft-shell clam it was 0.0133 for populations at a distance of thousands of kilometres. The study of Morgan et al. (1978) showed also little differentation between American populations in the enzyme loci which were studied by us, except locus Gpi. The lack of genetically subdivided populations was also observed by Caporale et al. (1997) in populations of $M$. arenaria from the New England coastline. Sequencing of the internal transcribed spacer (ITS-1) ribosomal DNA region showed no significant heterogeneity among the studied populations (Caporale et al., 1997). The genetic differentiation between populations can arise in consequence of isolation or selection pressure creating adaptations to local conditions, as was found in many marine invertebrates (e.g. Johannesson et al., 1995). Therefore, the lack of genetic differentiation between the studied populations may be consistent with a high gene flow (effective number of migrants per generation 18) and alleles neutrality in the analysed loci. However, since the soft-shell clam is an invasive species in Europe, the genetic population structure reflects historical and contemporary processes. It is known that high genetic similarity between populations might reflect a recent widespread expansion from a single population. Although the founder population (or populations) of the soft-shell clam was established in Europe about eight hundred years ago, rapid expansion in Europe could be a very important factor which is reflected in the observed genetic homogeneity between populations; especially since Morgan et al. (1978) found differences between populations in Gpi and other loci not studied by us. The similar phenomenon of high genetic similarity between distant populations was observed by Grant \& da Silva-Tatley (1997) in the gastropod Bullia digitalis. The authors suggested that high genetic similarity between populations could reflect allele neutrality and a high gene flow or recent rapid expansion (Grant \& da Silva-Tatley, 1997).

Similar genetic variability of American and European populations in loci coding the same enzyme systems suggests that European populations did not lose genetic variability due to founding events or several events of invasion. High genetic similarity between European populations and the results of the linkage disequilibrium analysis would also suggest that founding events may have had little impact on the gene pool of the newly established populations. Two causes are considered to be mainly responsible for the linkage disequilibrium: epistatic natural selection and random genetic drift (Ohta, 1982). Therefore, the linkage disequilibrium may reflect historical processes (selection under new environmental conditions, random genetic drift because of small size of founding populations) which had influence on the gene pool of pioneer populations. In this study the linkage disequilibria was found only in one population and involved rare alleles therefore was rather artefact (Black \& Krafsur, 1985). In this light the hypothesis that colonization processes had significant influence on the newly established populations has no support. However, since we do not have enough data about any parental population, this supposition should be confirmed by further study.

We would like to thank Izabela Wiater for collecting samples from the Gulf of Gdansk. We are grateful to Ko Verschuure and Roelof H. Bogaards from the Netherlands Institute of Ecology (Yerseke) for help in collecting samples and electrophoretical analyses, and Professor Philip Rainbow from The Darwin Centre, The Natural History Museum (London), for editing the English. This study has been made possible by a fund (to R.L.) from the Netherlands UNESCO Committee (no. ZZ0007). This is communication no. 3391 of the NI00-KNAW Netherlands Institute of Ecology.

\section{REFERENCES}

Alvarez-Buylla, E.R. \& Garay, A.A., 1994. Population genetic structure of Cecropia obtusifolia, a tropical pioneer tree species. Evolution, 48, 437-453.

Black, W.C. IV \& Krafsur, E.S., 1985. A FORTRAN program for the calculation and analysis of two-locus linkage disequilibrium coefficients. Theoretical and Applied Genetics, 70, 491-496.

Black, W.C. IV., 1997. BIOSYS-2. A computer program for the analysis of allelic variation in genetics. Fort Collins, CO: Colorado State University.

Blot, M. \& Thiriot-Quiévreux, C., 1989. Multiple locus fitness in a transfer of adult Mytilus desoliatonis (Mollusca, Bivalvia). In 23rd European Marine Biology Symposium University of Wales, Swansea. Reproduction, genetics and distributions of marine organisms (ed. J.S. Ryland and P.A. Tyler), pp. 251-259.

Caporale, D.A., Beal, B.F., Roxby, R. \& Van Beneden, R.J., 1997. Population structure of Mya arenaria along the New England coastline. Molecular Marine Biology and Biotechnology, 6, 33-39.

Chakraborty, R. \& Nei, M., 1977. Bottleneck effects on average heterozygosity and genetic distance with the stepwise mutation model. Evolution, 31, 347-356.

Cockerham, C.C. \& Weir, B.S., 1977 Digenic descent measures for finite populations. Genetical Research, 30, 121-147.

Ehrlich, P.R., 1986. Which animals will invade? In Ecology of invasions of North America and Hawaii Drake (ed. J.A. and H.A. Mooney), pp. 79-95. New York: Springer-Verlag.

Gallardo, M.H., Köhler, N. \& Araneda, C., 1995. Bottleneck effects in local populations of fossorial Ctenomys (Rodentia, Ctenomyidae) affected by vulcanism. Heredity, 74, 638-646.

Grant, W.S. \& Silva-Tatley, F.M. da, 1997. Lack of geneticallysubdivided population stucture in Bullia digitalis, a southern African marine gastropod with lecithotrophic development. Marine Biology, 129, 123-137.

Hedrick, F.W., Ginevan, M.E. \& Ewing, E.P., 1976. Genetic polymorphism in heterogeneous environments. Annual Review of Ecology and Systematics, 7, 1-32.

Hummel, H. et al., 1995. Uniform variation in genetic traits of a marine bivalve related to starvation, pollution and geographic clines. Fournal of Experimental Marine Biology and Ecology, 191, 133-150.

Hummel, H., Colucci, F., Bogaards, R.H. \& Strelkow, P., 2001. Genetic traits in the bivalve Mytilus from Europe, with an emphasis on Artic populations. Polar Biology, 24, 44-52. 
Hummel, H., Sommer, A., Bogaards, R.H. \& Pörtner, H.O., 1997. Variation in genetic traits of the lugworm Arenicola marina: temperature related expression of mitochondrial allozymes? Marine Ecology Progress Series, 159, 189-195.

Johannesson, K., Johannesson, B. \& Lundgren, U., 1995. Strong natural selection causes microscale allozyme variation in a marine snail. Proceedings of the National Academy of Sciences of the United States of America, 92, 2602-2606.

Lavee, D. \& Ritte, U., 1994. Genetic variability and success in colonization in two intertidal mussels. In Genetics and evolution of aquatic organisms (ed. A.R. Beaumont), pp. 168-176. London: Chapman \& Hall.

Levinton, J., 1973. Genetic variation in a gradient of environmental variability: marine bivalvia (Mollusca). Science, New York, 180, 75-76.

Menken, S.B.J., 1982. Biochemical genetics and systematics of small ermine moths (Lepidoptera, Yponomeutidae). Zeitschrift für Zoologische Systematik und Evolutionsforschung, 20, 131-143.

Morgan, R.P., Block, S.B., Ulanowicz, N.I. \& Buys, C., 1978. Genetic variation in the soft-shelled clam Mya arenaria. Estuaries, 1, 255-258.

Nei, M., 1977. F-statistic and analysis of gene diversity in subdivided populations. Annals of Human Genetics, 41, 225-233.

Nei, M., 1978. Estimation of average heterozygosity and genetic distance from a small number of individuals. Genetics, 83, 583-590.

Nei, M., Maruyama, T. \& Chakraborty, R., 1975 The bottleneck effect and genetic variability in populations. Evolution, 29, $1-10$.

Ohta, T., 1982. Linkage disequilibrium with the island model. Genetics, 101, 139-155.

Petersen, K.S., Rasmussen, K.L., Heinemeler, J. \& Rud, N., 1992. Clams before Columbus? Nature, London, 359, 679.
Ritte, U. \& Pashtan, A., 1982. Extreme levels of genetic variability in two Red Sea Cerithium species (Gastropoda: Cerithidae). Evolution, 36, 403-407.

Safriel, U.N. \& Ritte, U., 1986. Population biology of Suez Canal migration - which way, what kind of species and why. In Evolutionary processes and theory (ed. S. Karlin and E. Nevo), pp. 561-582. Orlando: Academic Press, Inc.

Selander, R.K., 1970. Behavior and genetic variation in natural populations. American Zoologist, 10, 53-66.

Silva, E.P. da \& Solé-Cava, A.M., 1994. Genetic variation and population structure in the tropical marine bivalve Anomalocardia brasiliana (Gmelin) (Veneridae). In Genetics and evolution of aquatic organisms (ed. A.R. Beaumant), pp. 71-82. London: Chapman \& Hall.

Strasser, M., 1999. Mya arenaria - an ancient invader of the North Sea coast. Helgoländer Meeresuntersuchungen, 52, 309-324.

Swofford, D.L. \& Selander, R.B., 1981. BIOSYS-1: a FORTRAN program for the comprehensive analysis of electrophoretic data in population genetics and systematics. Fournal of Heredity, 72, 281-283.

Wenne, R., 1992. Enzyme electrophoretic variation of the coot clam (Mulinia lateralis Bivalvia) along the Atlantic coast of the USA. Genetica Polonica, 33, 131-139.

Weir, B.S., 1979. Inferences about linkage disequilibrium. Biometrics, 35, 235-254.

Workman, P.L. \& Niswander, J.D., 1970. Population studies on southwestern Indian tribes. II. Local genetic differentiation in the Papago. American Fournal of Human Genetics, 22, 24-49.

Wright, S., 1965. The interpretation of population structure by Fstatistics with special regard to systems of mating. Evolution, 19, 395-420.

Submitted 6 May 2004. Accepted 19 July 2004. 